\title{
Audience as Community: Corporeal Knowledge and Empathetic Viewing
}

Karen Wood, University of Wolverhampton

This essay focuses on community in the form of audiences, and in particular, screendance audiences. A specific focus is given to a collection of screendance experiences from viewing a selection of contemporary dance films. The term screendance is used in this research as suggested by Douglas Rosenberg as "stories told by the body" and "not told by the body." ${ }^{1}$ What follows, for this essay, are theories borrowed from the discipline of audience and reception research detailing what we may perceive audiences to be and how the idea of 'audience' as a community may influence the way filmmakers approach the very audiences they hope to reach. Kinesthetic empathy will be used as a framework to understand the pleasures and displeasures that are experienced by the viewer from an embodied perspective. While considering kinesthetic empathy with audience and reception research, the main focus for this essay is nuancing the idea of audiences as a community that is enriched with corporeal knowledge. This knowledge reveals itself as empathetic and sympathetic viewing of the media.

Kinesthetic empathy can be loosely defined as the sensation of moving while watching movement, where the viewer can sense, as Ivar Hagendoorn points out, the "speed, effort, and changing body configuration" of the dancer, as if performing the movement themselves. ${ }^{2}$ The word 'kinesthesis' is derived from the Greek word kine-movementand aesthesis-sensation. Combining kinesthesis with 'empathy,' this concept emerges as an empathetic interaction between performer and viewer that embodies aspects of the performer's movement. This interaction is a sensory experience, perhaps facilitated by emotion, memory, and imagination.

This investigation into kinesthetic empathy and screendance audiences, described below, shows that the knowledge that the viewers are part of a collective, or indeed in the case of the experimental dance film audiences, are part of an immediate small collective, is a key factor in engagement with the viewed media. In focus groups created for this research, dance film viewers revealed that they experience enhanced attention to technical details. Therefore, I assert that the selection of films, with their different characteristics, create empathetic viewing experiences.

The International Journal of Screendance 5 (2015). 


\section{Approach}

Rather than 'audience' research, this essay engages in what is better termed 'reception' research as it focuses on processes involved in the reception of an artform and the resultant experience as reflection and memory. Audience research focuses on demographics such as gender, geographical location and mass consumption. Both William Sauter ${ }^{3}$ and Matthew Reason ${ }^{4}$ employ the term 'reception research' for their explorations into theatre audiences and their methodological enquiry. Although each has slightly different methodological approaches, their concerns encompass the collective and individual experience of audiences and the gathering of information on audiences' experiences through talk and other such methods, for example, drawing.

This type of reception research is qualitative and is used to examine individuals' interpretations of a particular phenomenon and, in this case, of particular media. According to John Creswell, qualitative research "begins with a worldview, the possible use of a theoretical lens, ${ }^{5}$ and studies a phenomenon through a specific approach to inquiry, collecting data, and analyzing this inductively for emerging themes. ${ }^{6}$

Through analysis of audiences' experiences of viewing dance on screen, I will show how empathetic viewing is created from the artistic aesthetic of dance made for camera. Qualitative reception research methods, focus groups, and diary writing were used to gather material on viewers' experiences of watching selected contemporary dance films. $^{7}$

The films selected for the participants to view were shown in the following clusters: first, Loose in Flight by Rachel Davies, Delia and George by Shelly Love, and Linedance by Alex Reuben; second, Flesh and Blood by Lea Anderson, The Wild Party by Rosie Kay, Three's A Crowd by Andy Wood. These films were selected from the artists' portfolios of work because of the filmic techniques employed in their creative process. They cover a variety of techniques including narrative structures, defamiliarised camera angles, and animation. This variation will be one of the factors I take into account in my consideration of the conditions associated with the experience of kinesthetic empathy in audiences.

For this project, fourteen participants took part in four focus groups. Focus groups gather data from a group of people and encourage discussion and interaction amongst the participants that can be valuable when exploring experience. Four focus groups were arranged over two days, two each day. Seven participants watched three of the films and the other seven participants watched three different films. The room contained a projector, large screen and speakers, which allowed the films to be shown on a larger scale than a TV screen would have permitted. The three films in each set were shown, one after another, to each group at the beginning of the session. Each participant was given a notebook to jot down any immediate thoughts he or she had on 
the films whilst viewing. After seeing the films, three exercises were conducted in relation to each film. The session ended with an open discussion about all three films.

Some problems arise when dealing with individual experiences. As a researcher, I rely on the viewers to externalize their experience and articulate this through talk or writing. I am asking them to discuss their experience of a feeling, sensation, emotion, or instinct that perhaps is indescribable using words. Group discussions can be one way of dealing with difficulties in expressing the inexpressible in addition to the opportunity to use other media, such as drawing as an alternative to talk-based methods. ${ }^{8}$

There are also moments where it is necessary to consider my own experiences of either participating as a performer or observing the screen media. By acknowledging my selfreflective thoughts, I hope to enrich the material and show an awareness of how my position as researcher has shaped the methodology. Indeed, my life experiences as performer, teacher, and researcher have impacted my stance in writing and affected my interpretation of the material. As Creswell notes, "how we write is a reflection of our own interpretation based on cultural, social, gender, class, and personal politics that we bring to research." ${ }^{9}$ It is important to highlight this factor, especially since with writing on embodiment and experience, one can relate to an interpretation through one's own corporeal existence.

\section{What is an audience(s)?}

From the advent of cultural studies in the 1960s and 1970s, audiences have become a popular area of research in the humanities and social sciences and there is now a vast amount of literature published on the topic, in particular on the television audience. There has been widespread debate concerning the effects of mass media on their audiences and how the media position themselves on key issues, such as politics.

An audience is commonly referred to as 'the audience' or 'it,' signifying a unified and singular consciousness. ${ }^{10}$ The idea that an audience is constructed from many consciousnesses is not reflected in the general singular use of the word 'audience.' In this essay, I employ the plural form, 'audiences,' to represent the many interpretive communities that constitute a larger whole. While I acknowledge the power of a collective presence, intersubjectivity, and the desire to belong to a homogenous entity, I also value the individuality of the viewers and their interpretive strategies.

Reason discusses how the audience is thought of as a "communal body"11 and how this communality is an essential element for many performers and spectators of live performance. It adds value to their experience, knowing that they are part of a unified presence. In addition to the desire for communality, however, Reason places importance on the identity of the individual and the subjective experience of the spectator. This has been emphasized by the broadcast media developments that allow audiences to fragment into sub-groups mainly due to the ownership of television sets 
and recording devices in every household. Furthermore, Reason discusses how, when trying to understand what engages audiences, focusing on aspects such as each particular medium and its content reduces the audiences to passive viewers ${ }^{12}$ rather than focusing on individual experiences that empower engagement. He states: "Each individual experience, in contrast, is to empower not only that individual as an active, engaged and consciously interpreting audience member, but also paradoxically empowers any voluntary engagement within a collective audience as a positive democratic act of communality. ${ }^{13}$

Helen Freshwater, theatre and performance theorist, supports Reason's claims and adds that it is important to recognize that the spectator brings "their own cultural reference points, political beliefs, sexual preferences, personal histories, and immediate pre-occupations to their interpretation of a production. ${ }^{114}$ In addition, Martin Barker, who researches film audiences, asserts that spectators "bring their social and personal histories with them. ${ }^{15} \mathrm{~A}$ parallel can be drawn here with Creswell's previous comments about how we bring our social, political and cultural interpretations to our research and, therefore, other activities (such as being an audience member) that require interpretation. Thus, audiences are formed from individual identification in cultural and social communities and identify with the communal act of "audiencing."

"Audiencing" is a concept initially borrowed from media studies and now widely used in audience research. ${ }^{16}$ In the act of spectating, we are consciously active in various cognitive, sensory, and participatory modes of interpretation. Therefore, our subject positions and interpretative strategies (discussed further below) are an important point of departure, as one becomes an active audience member through choice. Audiencing is not context-specific, but is something that happens in spectating situations.

Screendance audiences differ depending on the context of the viewing medium and are a new challenge for today's viewing because of the fragmented way we can view media, for example, on the internet, on mobile devices and multiple platforms available in the home. Abercrombie and Longhurst, who are audience researchers, claim, "media consumption in the 1990 [was] essentially a fragmented experience. ${ }^{.17}$ In the 21st century, the "fragmented experience" is even more complex due to the multiple platforms available. Therefore, when discussing the dance films, I have to consider the viewers as having an individual experience but as also belonging to a larger, mass community of media-created imagined viewers ${ }^{18}$ and how this affects their experiences. In addition, the viewers are part of a smaller audience, having their own individual experience and being part of a collective community for a selection of single viewings. This is similar to how one would view films at a dedicated dance film festival. However, for this research, the opportunity to discuss their experiences in the focus groups immediately with other viewers might change their experience and the meaning of that experience for them. Being part of a community and having an individual experience are not mutually exclusive, however, and one may even enhance the other. 
According to Barker, there is a tendency among researchers to singularize the audience rather than engage with a variety of audiences who belong to different interpretive communities. As Stanley Fish, a reader response theoretician in literature studies, has argued, interpretive authority does not reside with the author; it could, rather, reside with the reader, or a community of readers. Interpretive communities experience collective understanding and shared meanings in the interpretation of a text. Interpretive communities exist in different forms and, as spectators, we can find ourselves taking different, and sometimes conflicting, subject positions vis $\dot{a}$ vis the same performance. A subject position is where we locate ourselves on a subject from a perspective that makes the most sense to us. Alice Rayner points out that when occupying different subject positions, "sometimes I hear you from my position as a woman, sometimes as a professor, sometimes as a mother, sometimes as bourgeois."19 This can be the same for a dance audience member; one can be a dance enthusiast, feminist, mother, worker-all at the same time. People belong to such communities and show commitment and motivation to such activity, with a desire to experience a sense of belonging to a larger collective community. For Barker, viewing from a particular position additionally introduces an internal mental schema or "viewing strategy" to assess works of art, for example, which facilitates "making sense" of the artwork. $^{20}$ Spectators employ a viewing strategy that is drawn from their beliefs, motivations, competencies, expectations and values. Viewing performances through this strategy imparts meaning to one's life. Reason concurs with this view: "Spectators (both individually and collectively) actively interpret and place value upon what they see and experience. In doing so, they actively construct what the performance (and what being part of an audience) means to them culturally and socially." ${ }^{21}$

The consideration of viewing strategies and subject positions can be useful when exploring screendance audiences. These concepts can be employed to analyze individual and collective responses to the media and explore how audiences construct their interpretations. This may provide some fundamental information on how the use of different filmic techniques and narratives are experienced by screendance audiences. The next section will reveal viewers' responses to the media and consider the viewing strategies and interpretative communities that are uncovered.

\section{Viewers' responses to screendance}

I will start this section with viewers' responses to the selected contemporary dance films screened in the focus groups. The following example illustrates the response of one viewer, Chantelle, ${ }^{22}$ to Three's a $\mathrm{Crowd}_{1}{ }^{23}$ and establishes her reader position. Three's a Crowd was independently produced and directed and is a low-budget film. The film contains one male and one female dancer doing an improvised duet in a derelict outdoor space. Their movement is accompanied by diegetic and non-diegetic sound; the non-diegetic sound is two pieces of tango music. Chantelle comments on where the duo's improvised struggle with each other reaches the floor: "[l] thought ow... they 
seemed to be on a concrete floor and all that movement on the floor, I just kept thinking they are just going to graze themselves and it looked kind of very, very rough. ${ }^{24}$

Her reader position-as a mother, teacher and recreational dancer-and viewing strategy suggests caring and mindfulness of the surface that the dancers are performing on. Chantelle recognizes the contact with the floor and the possibility of injury to the performers. She sympathizes with the performers moving on the gravelly, uneven floor surface, and empathizes with the sensuous imagery that evoked a memory of the urban environment. This interesting slippage from sympathy to empathy shows a movement of heightened imaginative engagement. Reason and Reynolds suggest that kinesthetic empathy is an "embodied and imaginative connection between the self and the other," and kinesthetic sympathy is explained as an appreciation and admiration of the dancers' effort and skill. ${ }^{25}$ In Chantelle's response, her corporeal knowledge is revealed through kinesthetic empathy and sympathy with the dancers in the image, which may show her investment in viewing the film. In addition, the way the camera moves with kinesthetic sensitivity with the performers may encourage this investment from the viewer, as Chantelle shares: "the way the camera moves in and out with the dancers, you kind of feel close." Chantelle displays a sense of anticipation at the potential for the performers to become injured, which may be experienced through the tactility of the haptic visuality of the image. ${ }^{26}$

In a further example, another viewer, Julia comments on a moment when she empathizes with Akram Khan's body's contact with the surfaces on which the performer was dancing. This film, Loose in Flight, ${ }^{27}$ shows Khan dancing inside a derelict building and then quickly changes to a shot of him dancing outside in an industrial area. Julia says: "the sequence on the mat outside with the barrel jump into the... the fluidity and the lightness... and you're making that look effortless and yet you are dancing that on concrete." Julia's kinesthetic sympathy reaches out beyond the physical realms of Khan's musculature to the skin's superficial contact with the concrete surface on which he is performing. Therefore, Julia identifies with the inner mechanisms of the perceived movement and the tactile exterior of the body, using the proximal sense of touch. This experience is another example of what Laura Marks refers to as "haptic visuality. ${ }^{12}$

These types of experiences with their varying requirements of attention and focus, provide an insight into the micro-aspects of the reception of screendance, or the screendance viewer's emotional and sensorial experience of watching. ${ }^{29}$ Jacqueline Martin and William Sauter describe the micro-aspects of the reception of theatre as emotional reactions and thoughts that occur when watching a theatrical performance..$^{30}$ Micro-aspects identified in this study may be challenging for the spectators to put into words: subtle and intricate, felt, tactile, and kinesthetic experiences can be difficult for viewers to express verbally. 
Viewing dance is usually conducted with friends or family members and the fact that some of the viewers were friends seemed appropriate when trying to encourage a relaxed, natural setting. ${ }^{31}$ Nevertheless, there is a certain pleasure in exploring topics in group contexts, as communities, and the viewers appeared to enjoy discussing the films amongst themselves and engaging in dialogue about their thoughts and feelings.

The film discussed here is Shelly Love's Delia and George, which depicts a couple at a table eating breakfast and reading the newspaper. The film progresses in reverse:

J: Because there wasn't... it was... are we going backwards? What? So it set up an implication of a narrative and didn't quite deliver for me. I ended up feeling like: 'oh that's a clever idea, and that's a clever idea and I think this looks really nice' but... for me whatever the narrative was or was not, it didn't seem to me to be clear enough

L: I had the same feeling, I wrote its very abrupt ending, irritating to feel like there's no conclusion... and you know, whenever expectations are disappointed there's a frustration, it's not always a negative thing because in fact I liked the way it made me question, you know, what I think dance is and I liked that question that came out of it but the experience of watching it was frustrating because of that...

P: Do you think we were projecting the need for a narrative on to it?

L: Yes. I think I was.

P: I think I was too. But looking back now I'm starting to wonder if that was just me going 'oh look, there should be a narrative here'

( $\mathrm{J}$ and $\mathrm{P}$ agree)

This example illustrates the viewers' experience of narrative as a story with characters and allowed me to consider how this can be a condition of engagement. In addition, narratives have logic and the viewers had expectations of finding a narrative within the film. However, in the hybrid form of screendance, the idea of dance as narrative can be structured with movement. Movement narrative involves choreography that constructs its own story. Aaron Anderson discusses movement narrative as when the "movement itself aims to convey a story or narrative." ${ }^{32}$ Anderson analyzed the movement narrative of martial arts films and compared the movement within these films to dance. Fight choreography, its execution, and the director's desired response from the spectator require kinesthetic engagement, as does dance choreography. The spectator has a kinesthetic relationship to the martial arts expert executing the fight choreography; the movement projects power of the body. Although the spectator may not be able to perform the movement him or herself, he or she can kinesthetically appreciate the power and skill required to perform the choreography because we watch with an awareness of our own body. Similarly, choreography in dance films requires the 
spectator to have a kinesthetic relationship with the performer. Comparable to martial arts films, dance film employs narrative strategies to encode narrative from the movement.

A further example from Lauren refers to making a narrative out of what we view and this is an act that audiences regularly participate in:

I realize I try to make a narrative out of it or put one on it. And similar to you [referring to Julia], when I go to watch dance I think I can just appreciate the movement and I feel happy doing that but I'm sure subconsciously I'm doing something else.

In some abstract contemporary work, we may find a non-linear or vertical direction ${ }^{33}$ narrative that we are then required to 'fill in the gaps.' Claudia Kappenberg states: "the absence of narrative and original context creates a void that can only be filled by the viewer." ${ }^{\prime 34}$ Peter, in response to Lauren, captures the essence of meaning-making through narratives and stories in his comment: "I love that. I love that about everything that you can tell stories; a story in itself. And actually that's one of the things I love about dance, it's often so abstract, it's a challenge to find your way through it." Life, the way Peter describes it, takes the form of stories or we construct stories in order to make sense of life experiences. As spectators, we have certain expectations that narrative will provide character interaction and action-based movement. As viewers, we create the narrative to make it meaningful and engaging whilst in the act of audiencing. This may further contribute to our engagement and pleasure in watching screendance.

It is difficult to ascertain whether the material discussed is about a bodily experience and is felt, rather than articulated in words. Language is our primary mode of communicating and reflecting on experiences and words are the most flexible system for articulation. Reflecting through language creates an indelible impression on our memories. Yet, words can sometimes prove to be inadequate when describing the richness of an experience. Plantinga acknowledges the insurmountable task of language in determining the emotional qualities of film and music. ${ }^{35}$ Reason also acknowledges the difficulty in the use of language as a reflective device when discussing experiences of watching live theatre and dance but also defends reflection as methodologically sound. He discusses the traces of experience, which, when discussed in a group context after a performance, affirm one's individual memory and suggests that for most people, conversation post-performance acts as part of the experience. ${ }^{36}$ An Australian study conducted by Renee Glass on audience members of a live dance performance suggests that people,

when given the opportunity to reflect on their own experience with the work, enjoy being asked their opinion, and the freedom to interpret the work in any way they want. Perhaps what is important is not being given 
pre-performance information, but the opportunity to reflect on one's own interpretation, understanding and connection with the piece. ${ }^{37}$

The viewers in the current research engaged in reflection after viewing the films. The conversations that took place between the viewers seemed to affirm their thinking and interpretation of a film. One viewer, Lauren, comments: "I'm getting more out of these films because I'm reflecting and talking about it."

As Glass ${ }^{38}$ and Reason ${ }^{39}$ assert, and as Lauren comments, reflection post-experience can provide a platform for engaging in aspects not yet realized through direct affect and can implant traces of the experience in one's memory. Equally, post-experience conversation acts as part of the experience and assists the audience members in articulating thought and sensation.

To summarize, viewers' post-experience reflective conversations may contribute to the screendance viewing experience by allowing articulation through language, which may enhance connection with the films. Using focus groups to set up this environment has shown that this gives viewers the opportunity to discuss with other audience members their interpretation and understanding of the films and how this may stimulate kinesthetic engagement. Kinesthetic response and language are crucial to screendance audiences, as the medium demands this attention. Screendance is attentive to narrative and choreographic structures and therefore requires interpretive communities to engage with and provide meaning to the artwork.

The focus groups conducted for this research have exemplified the importance of interpretive communities when experiencing screendance. The diverse subject positions found in such communities are rich with cultural and social aspects that are fundamentally motivating for screendance researchers. Researchers would do well to consider the fruitfulness of gathering screendance audiences to obtain material in order to better inform filmmaking practices. Embedded in these audiences are fertile interpretative communities that can contribute to expanding our body of knowledge and further research for the artform.

The research inspires further thought on how we want to construct our social worlds and what we want to be identified with. Furthermore, there is a sense of belonging to a community of people who, at that same moment of viewing a film, are potentially united in the experience. A community becomes much more engaged and invested in the media. Therefore, in addition to seeking kinesthetic pleasure from watching dance, we know that we will be part of a community of people interested in and identifying with aspects of dance, which constructs meaning around the role of watching dance on screen. 


\section{Biography}

Karen is currently a dance practitioner/ researcher/ educator. She works for the University of Wolverhampton as a Dance Lecturer and at the Centre for Dance Research at Coventry University, as a Research Assistant. Karen is also working on artistic projects, supported by Arts Council England, collaborating with other art forms, such as neuroscience, fine art, lighting design and music were she creates and performs in dance pieces for traditional and non-traditional spaces.

She has a keen interest in the inclusive training of young dancers and, in particular, how supplementary training helps to improve dancers' knowledge of their body and to improve performance. She obtained her MSc in Dance Science at Trinity Laban, London in 2006 where she continued to work until securing an AHRC studentship to further study a PhD in dance at the University of Manchester. Her recently completed PhD project investigated the experience of kinesthetic empathy when viewing dance on screen. She is also interested in how dancers acquire kinesthetic, embodied sensibilities and how this relates to improvisation and musical structure.

\section{Notes}

${ }^{1}$ Rosenberg, "State of the Arts," 13.

2 Hagendoorn, "Some speculative hypothesis," 79.

3 Sauter, "Thirty Years of Reception Research."

${ }^{4}$ Reason, "Asking The Audience."

${ }^{5}$ Creswell, Qualitative Enquiry, 37.

${ }^{6}$ For the PhD thesis, a phenomenologically-informed approach was adopted to uncover individuals' lived experiences of the concept of kinesthetic empathy. The methodology was also informed by ideas of embodiment taken from embodied and social phenomenologies, aesthetics and cognitive research. This approach enabled me to describe the viewers' experiences of viewing screendance and to look for commonalities between experiences that allowed themes to emerge from the research material. Allowing themes to emerge is an essential feature of phenomenological inquiry.

${ }^{7}$ The gathering of information from viewers was conducted as part of PhD research completed at the University of Manchester in 2012. My PhD thesis was titled Kinesthetic Empathy and Screendance Audiences.

${ }^{8}$ Reason, "Asking The Audience."

${ }^{9}$ Creswell, Qualitative Enquiry, 179.

${ }^{10}$ Freshwater, Theatre and Audience.

${ }^{11}$ Reason, "School Theatre Trips," 8. 
${ }^{12}$ Classic cultural theory takes the view that mass media imitates a "hypodermic needle" through which it "injects opinions and attitudes directly into the audience" creating passive viewers. Gripsrud, 28.

${ }^{13}$ Reason, "School Theatre Trips," 10.

${ }^{14}$ Freshwater, Theatre and Audience, 6.

${ }^{15}$ Barker, "I Have Seen The Future," 124.

${ }^{16}$ See About Performance 10, entitled "Audiencing: The work of the spectator in live performance."

${ }^{17}$ Abercrombie and Longhurst, Audiences: A Sociological Theory, 33.

${ }^{18}$ See Benedict Anderson, Imagined Communities.

${ }^{19}$ Rayner, "The Audience: Subjectivity," 4.

${ }^{20}$ Barker, "I Have Seen The Future," 134.

${ }^{21}$ Reason, "School Theatre Trips," 9.

${ }^{22}$ When a viewer is named in this paper, the name is a pseudonym and is therefore anonymous.

${ }^{23}$ Wood, Three's a Crowd (2007).

${ }^{24}$ All viewer quotations are taken from focus groups that took place in February 2010.

${ }^{25}$ Reason and Reynolds, "Kinesthetia, Empathy and Related Pleasures," 23.

${ }^{26} \mathrm{Haptic}$ visuality values the proximal senses of touch, feel and smell over the distant senses of seeing and hearing and evokes the sensory network. For more on haptic visuality, see Marks, The Skin of the Film.

${ }^{27}$ Davies, Loose in Flight.

${ }^{28}$ Marks, The Skin of the Film.

${ }^{29}$ Macro-aspects relate more to demographical information and generality of the behavior of audiences.

${ }^{30}$ Martin and Sauter, Understanding Theatre.

${ }^{31}$ However, having friends discuss the films in this setting may also have an adverse affect and could impede the research by gently persuading their friends to think from their view.

${ }^{32}$ Aaron Anderson, "Fight Choreography," 3.

${ }^{33}$ The opposite notion to horizontal movement or linear narrative is what Maya Deren terms vertical direction and is characterized by more "ephemeral elements of mood, tone and rhythm" (Haslem 2002). Erin Brannigan (2002), refers to Deren's association of the vertical movement with 'poetic structure.' This is concerned with quality and depth.

${ }^{34}$ Kappenberg, "The Logic of the Copy," 29.

${ }^{35}$ Plantinga, Moving Viewers.

${ }^{36}$ Reason, "Asking The Audience."

${ }^{37}$ Glass, Observer Response, 107-8.

${ }^{38} \mathrm{lbid}$.

${ }^{39}$ Reason, "Asking The Audience." 


\section{References}

Abercrombie, Nicholas and Brian Longhurst. Audiences: A sociological theory of performance and imagination. London: Sage, 1998.

Anderson, Aaron. "Fight Choreography and Kinesthetics, part 2." Jump Cut: A Review of Contemporary Media 42 (1998). Accessed 19 Jan. 2011.

http://www.ejumpcut.org/archive/onlinessays/JC42folder/anderson2/action2.html.

Anderson, Benedict. R. O'G. Imagined Communities: Reflections on the origin and spread of Nationalism. London and New York: Verso, 1991.

Barker, Martin. "I have seen the future and it is not here yet...; or, on being ambitious for audience research." The Communication Review 9.2 (2006): 123-141.

. "The Pleasures of Watching an 'Off-beat' film: The case of being John Malkovich." Scope 11 (2008). Accessed 22 Sept. 2011.

http://www.scope. nottingham.ac.uk/article. php? issue=11\&id=1020.

Brannigan, Erin. "Maya Deren, Dance and Gestural Encounters in Ritual in Transfigured Time." Senses of Cinema (2002). Accessed 17 Nov. 2009.

http://sensesofcinema.com/2002/filmmaker-profiles/deren/

Connolly, Brianne. "A cubist approach to analyzing interpretive communities." Orange 3.1. (2006). Accessed 13 Oct. 2010. http://orange.eserver.org/issues/3-1/connolly.html.

Creswell, John. W. Qualitative Inquiry and Research Design: Choosing among Five Approaches. California: Sage, 2007.

Delia and George. Dir. Shelly Love. Chor. Shelly Love and Gerard Bell. Prod. Catherine Willmore. England. 2005. http://www.shellylove.co.uk/films/delia\&george.html.

Flesh and Blood. Dir. and chor. Lea Anderson. Prod. Margaret Williams, Anne Beresford, MJW Productions. 2005. DVD.

Freshwater, Helen. Theatre \& Audience. Basingstoke: Palgrave Macmillan, 2009.

Glass, Renee. "Observer response in contemporary dance." Thinking in four dimensions: Creativity and Cognition in contemporary dance. Eds. Robin Grove, Catherine Stevens, Shirley McKechnie. Carlton, Victoria: Melbourne University Press, 2005. 107-120. 
Gripsrud, Jostein. "Television, broadcasting, flow: Key metaphors in TV theory." The Television Studies Book. Eds. Christine Geraghty, David Lusted. London: Arnold, 1998: $17-32$.

Hagendoorn, Ivor. "Some speculative hypothesis about the nature and perception of dance and choreography." Journal of Consciousness Studies 11 (2004): 79-110.

Haslem, Wendy. "Maya Deren: Eleanora Derenkowsky" Senses of Cinema, 23 (2002). Accessed 01 May 2009. http://sensesofcinema.com/2002/great-directors/deren-2/.

Kappenberg, Claudia. "The logic of the copy, from appropriation to choreography." International Journal of Screendance 1.1 (2010): 27-40.

Line Dance. Dir. Alex Reuben. Chor. Afua Awuku and Alex Reuben. Prod. Margaret Williams; Caroline Freeman, MJW Productions. 2003. MySpace.

Loose in Flight. Dir. Rachel Davies. Chor. and perf. Akram Khan. Prod. Rosa Rodgers. 1999. DVD.

Marks, Laura. The Skin of the film: Intercultural cinema, embodiment and the senses. U.S.A.: Duke University Press, 2000.

Martin, Jacqueline and William Sauter. Understanding Theatre: Performance analysis in theory and practice. Stockholm: Almqvist \& Wiksell International, 1995.

Plantinga, Carl. Moving Viewers: American film and the spectator's experience. London: University of California Press Ltd, 2009.

Rayner, Alice. "The Audience: Subjectivity, community and the ethics of listening." Journal of Dramatic Theory and Criticism 7.2 (1993): 3-24.

Reason, Matthew. "School theatre trips: For life, for learning, for fun?" International Conference of Cultural Policy Research. Vienna, Austria. 12-16th July 2006.

. "Drawing the theatrical experience: How children watch theatre." York, York St John University, Scottish Government Education Department (2008): 1-16.

. "Asking the audience: Audience research and the experience of theatre." About Performance 10 (2010): 15-34.

Reason, Matthew and Dee Reynolds. "Kinesthesia, Empathy and related pleasures: An inquiry into audiences experiences of watching dance." Dance Research Journal 42.2 (2010): 49-75.

Rosenberg, Douglas. "Proposing a theory of screendance." Screendance: The state of the art proceedings, ed. Jessica Vokoun. American Dance Festival. Duke University, Durham NC, 6-9 July 2006. 15-16. 
Sauter, William. "Thirty years of reception studies: Empirical, methodological and theoretical advances." About Performance 10 (2010): 241 - 263.

Three's A Crowd. Dir. Andy Wood. Chor. Gabriel Koch and Francesco Schiano. Prod. Sound Alibi Productions and Dance Fields Productions. 2007. YouTube.

The Wild Party. Dir., Chor. and Prod. Rosie Kay. 2005. http://rosiekay.co.uk/work/thewild-party-film/ 